\title{
The League of Nations, Ethiopia, and the Making of States
}

\section{Ethiopia as a Lens on Statehood and State-Making}

In the late nineteenth century, Abyssinia, though nominally recognized as an independent state, remained on the fringes of the international legal order. From 1906, it was the subject of a "Tripartite Agreement" in which Britain, France, and Italy undertook to preserve the integrity of Abyssinia-yet reserved their respective interests should the country collapse. ${ }^{1}$ During World War I, Italian, and even some British, officials anticipated bringing Abyssinia under protectorate. ${ }^{2}$ This did not eventuate, but American planners took for granted that "Abyssinia has no place in" the future League. Abyssinia, alone of the candidates then under discussion, was self-evidently disbarred. ${ }^{3}$ Yet, in 1923, to "prolonged applause," the League Assembly voted unanimously to admit Abyssinia as a member. ${ }^{4}$ This admission was perceived by contemporaries as a startling expansion, and flattening, of a Eurocentric, hierarchical "family of nations." Indeed, the British foreign secretary fretted privately that "if Abyssinia is admitted there will be no future ground for excluding anybody." ${ }^{5}$

This essay takes Ethiopia as a case study of how the League refracted approaches to statehood and belonging for polities on the margins of the "family of nations." Unlike many other doctrinal or historical treatments, this essay does not focus on a single juridical concept or doctrine. Rather, it traces the flux within and between concepts like sovereignty, statehood, recognition, and admission to the League. It pays particular attention to the way the League as an institution shifted the forums for, and substance of, judicial approaches to statehood and their relation to military force, bureaucratic organization, and political structures. ${ }^{6}$

Interwar thinking about statehood_or the relations among people, territory, and political authority more broadly-is admittedly multifaceted. This period was one of profound contestation over the relationship between law and the state. ${ }^{7}$ Peace settlements saw the construction of new political and territorial orders, grounded in sometimesconflicting logics of historic right, self-determination on national or ethnic affiliation, and plebiscitary democracy; but inflected too by power politics. ${ }^{8}$ Innovations under League auspices, from the crafting of mandates to new arrangements for territorial administration, suggested novel and sometimes divergent avenues in thinking about sovereignty, statehood, and rule. The League put existing tensions - between a world of "powers" ordered hierarchically and a renewed commitment to nominal sovereign equality, and between an abstract notion of the state and the realities of governance in empires-under new pressure. ${ }^{9}$

The Ethiopian example brings to light a distinct and important part of this larger 
picture. It reveals the League of Nations "making" states in several different ways. Most obviously, the existence of the League required formal criteria for membership, forcing new articulations of what it was to be a state worthy of full membership in the international legal order. Such articulations were shaped, in turn, by the way the League changed the modalities of interstate interaction. The League made possible proceduralized, often public, exchanges on a footing of notional equality, which helped amplify previously marginalized voices in the initial debates over admission. Beyond admission, the League offered avenues through which Ethiopia could assert its own formal status_ostensibly already secured — as a state equal to other members, but also a potential mechanism for collective foreign intervention.

In substantive terms, Becker Lorca suggests that Ethiopian admission reflected an imperfect shift from a nineteenth-century "standard of civilization," with strong cultural and religious dimensions, to a "more concrete" and ostensibly culturally neutral paradigm of "statehood." 10 At least superficially, this was a shift from Eurocentric criteria, applied most authoritatively by European powers and publicists, to facially objective criteria applicable by any observer. On the other hand, Rose Parfitt questions the extent to which new criteria really broke with older cultural and racial hierarchies. She emphasizes that Ethiopia's admission was subject to special obligations that encoded, rather than transcended, inferiority and shows how the League machinery accommodated, even fostered, plans for the coercive reconfiguration of Ethiopia sovereignty in the I930s. ${ }^{11}$

Here, I suggest a somewhat distinct reading. I argue that the Ethiopian case shows not so much a coherent interwar reformulation of statehood as an absence of any compelling formulation. Precisely when criteria for admission to a newly institutionalized international community were being formalized, there was a curious absence in the League of candid discussion about political authority and what might crudely be called state capacity, however extensively these matters were discussed elsewhere. Criteria on which applications for admission were examined assumed-but did not explicitly demand-many of the attributes that had loomed large in nineteenth-century discussions. Where European officials invoked formal criteria, these were clearly not wholly capturing conscious and unconscious assumptions about the nature of statehood. The perceived lack of certain attributes in Ethiopia_-and the unsatisfactory nature of the criteria themselves — was palliated only by a remedial view of League admission. Formal criteria were, implicitly, waived. Admission was less an acknowledgment of status as fact than a portal to statemaking as process, in which the League Council might play an active role.

This approach rendered the League's "making” of Ethiopian statehood contingent upon the interests of the European imperial powers, among other things. The linkage of admission and League-sponsored advice on Ethiopian administration-which might have enabled far-reaching interventions into Ethiopia-was ultimately not operationalized, until taken up opportunistically by Italy. The absence of concerted action earlier was in part a result of inter-imperial competition among Britain, France, and Italy, turned to advantage by Ras Tafari. But it also illustrated the limits of contemporary European thinking about processes of state-making. Just as there was uncertainty about the very definition of a state worthy of membership in the international order, there was little theorization about how Ethiopia might reform, beyond approaches extrapolated from imperial administration or 
the mandate system. It was in Ethiopia itself, under Ras Tafari, that one saw more concrete and experimental approaches to state-making.

This same contingency was present in the League's procedural dimensions. Ras Tafari was able to make occasional use of the platform and procedures associated with the League to assert Ethiopian interests in ways not possible within nineteenth-century diplomatic practice. Italian expansionism and Anglo-French appeasement limited the power of League mechanisms to safeguard Ethiopia's interests in the I930s, but Ethiopia's use of the League to condemn the League's own failure may have had resonance over the longer term, helping ensure Ethiopia's re-emergence as a state after World War II.

The Ethiopian trajectory offers a new perspective on interwar shifts. It counters the more abstract European (if not German) debates about the nature of the state that often dominate intellectual histories of international law, and shows how new institutional sites of interaction inflect the articulation of ideas like statehood. The Ethiopian case draws attention to the range and complexity of state-making and statecraft occurring outside the European or League-dominated context. The interwar episode may also, I argue, enrich our sense of longer twentieth-century chronologies. Ethiopia is unusual in its political trajectory: one of only a few African polities to retain a nearly unbroken claim to independence from the late nineteenth century into the present, and to articulate itself for much of this time as an empire implicitly comparable in structure to contemporary European empires. Yet precisely these unusual characteristics make Ethiopia revealing, by forcing the articulation of assumptions that have gone unspoken in other cases. In particular, the Ethiopian case challenges a narrative that locates pathologies of peripheral and "failed" statehood in post-I945 decolonization. The Ethiopian case suggests that ambivalence about what kind of state was required in an institutionalized, culturally diverse international order long predated 1945. Indeed, the "failure" might lie in the imagination of the state, and how it could be integrated into a newly constituted international legal and political community.

\section{The Nineteenth-Century "Family of Nations" and its Fringes}

In the late nineteenth century, the status of particular polities vis-à-vis a larger international community was approached through a largely Eurocentric "standard of civilization." Although contemporary treatments - and later commentary-underscore the importance of a common religious and cultural core to this "standard," the standard also encompassed governmental machinery, including the government's ability to assert authority over the whole of its territory. ${ }^{12}$ This machinery was, in turn, a functional precondition for other markers of "civilized" status of particular importance to European commerce-like the judicial system, protection of foreign nationals' persons and property, and fulfilment of obligations under the law of nations. ${ }^{13}$

Despite the specificity of the "standard of civilization," it never functioned in a binary way. Polities might be recognized as sovereign states, at least in and for the purposes of treaty-making, but this status did not necessarily amount to full membership in the "family of nations." ${ }^{14}$ Ethiopia existed on the fringes of this system, and exemplified its complexities. Successive rulers in the Ethiopian empire had been able to consolidate power through alternating cooperation and conflict with European powers in adjacent territories. ${ }^{15}$ Menilek II (then negus or King of Shoa, one of two kings under Emperor Yohannes IV, r. I872-I889), solicited weapons from, and signed treaties with, Italy. When 
Ethiopia was attacked by Mahdist forces from the Sudan, and Yohannes IV was killed, Menilek's dealings with the Italians helped position him to prevail over Yohannes's son and heir, and proclaim himself emperor in March 1889.

Following his accession, Menilek entered into the Treaty of Wichale with King Umberto I of Italy, settling Italo-Ethiopian relations, and acceded in I890 to the General Act of the Brussels Conference relative to the African Slave Trade, a key article of which committed "[powers] exercising sovereignty or protectorate in Africa . . . to proceed gradually, as circumstances permit ... with the repression of the Slave Trade." ${ }^{16}$ The entry into treaties at least implied recognition of Ethiopia as an independent state. However, a key provision of the Treaty of Wichalé concerning relations between Italy and Ethiopia was ambiguous_ - or, even intended by the Italians to deceive. ${ }^{17}$ The Italian government claimed Ethiopia as a protectorate under the Berlin Congress regime for the management of claims to African territory. Menilek denied any protectorate existed. Italy tried to assert its supposed rights by force, but suffered a dramatic defeat at the Battle of Adwa (I896).

Ethiopian victory at Adwa, felt as a shock across Europe, secured recognition by Italy of Ethiopia's "absolute independence . . . as a sovereign and independent state." 18 However, Ethiopia remained confounding to a "standard of civilization" that tended to link Christianity, military prowess, and European forms of government together. Ethiopia's adherence to an ancient Christianity, and military success, vindicated its standing against some aspects of this civilizational account, and Menilek's modernization projects, pursued with the assistance of foreign advisers and foreign-educated nationals, created institutions and infrastructure like schools; mail, telephone, and telegraph services; and a railway, operated by a French concessionaire, which would, by 1917, connect Addis Ababa to the coast at Djibouti. ${ }^{19}$ But European powers considered modes of government and administration of justice divergent enough from European norms to warrant assertions of extraterritorial jurisdiction. ${ }^{20}$

Menilek's empire encompassed dozens of other ethnic and linguistic groups, some Muslim and others adhering to a range of indigenous religions. Beyond Addis Ababa, imperial authority was mediated through rases (variously translated as "heads," "governors," or "dukes") exercising considerable independent authority. Surrounding European colonies subject to "indirect rule," and the Somaliland protectorates, administered from the coast with limited reach into the hinterland, had similarly layered and limited control over territory. But Ethiopia was unique in having deeply entrenched slave-raiding and slavetrading practices, which had been central to the expansion of the empire and endured thereafter, although Menilek had formally prohibited sale and purchase of enslaved people in I875. Enslaved people worked in domestic contexts far removed from the plantations of European colonies and had some social mobility, but circumstances of capture and transfer were brutal, and raiding devastated whole regions. ${ }^{21}$

Despite formal independence after 1896, Ethiopia was left physically, juridically, and procedurally vulnerable. Ethiopia lacked any independent access to the sea and was thus dependent on European colonial powers controlling surrounding territory (particularly the French in Djibouti) for the importation of vital goods, including firearms. Paradoxically, recognition of Ethiopia as a territorially bounded polity threw into relief the weakness of the imperial center in actually controlling the entirety of the territory. ${ }^{22}$ Britain complained regularly about cross-border slave-raiding. 
Ethiopia's ambiguous status was reflected in treatment by publicists in treaties, and in diplomatic interactions. ${ }^{23}$ The 1906 "Tripartite Agreement" among Britain, France, and Italy, prompted by Menilek's failing health, spoke with two voices about Ethiopia's future. It described the status quo with reference to border delimitation agreements made by Italy as "protector," yet proclaimed that the conventions mentioned "do not in any way infringe the sovereign rights of the Emperor of Abyssinia." ${ }^{24}$ The European powers undertook that, in the event of disturbance of the status quo, they would "make every effort to preserve the integrity of Ethiopia” but, in any case, concert to protect each other's interests. A separate agreement bound the European powers to supervise the import of arms. ${ }^{25}$ Ethiopia's liminal standing was reflected, too, in its position on the margins of diplomatic dealings, the Ethiopian court having only limited, belated access to agreements directly concerning Ethiopia.

\section{The League System and the Idea of the State}

The upheaval of World War I opened possibilities for a profound restructuring of relations among people, territory, and political authority. The radical potential of anticolonial nationalism and "minorities" protections that would have secured broader racial equality were quickly curbed, but structures of mandate colonialism, minorities supervision, and territorial administration seemed to hold out new trajectories of state-creation and development. The international community, as incarnated in the League, would cultivate states of the right kind to function in a quasi-universal international order.

As mentioned earlier, approaches to statehood and belonging in the League were not necessarily coherent. Pathways to original membership, including being a signatory to the Treaty of Versailles, or a separate invitation to accede to the Covenant (doled out by the major powers), facilitated the membership of many polities that would not have satisfied the criteria for admission after the League's founding (on which this essay focuses). ${ }^{26}$ The British Empire presented particularly anomalous cases: the empire as a whole was a member of the League, yet the four dominions (not yet independent states) and India (which fell even further short of the "self-governing" threshold applicable to applicants for admission after the League's establishment) were also original members. ${ }^{27}$ While criteria for admission after the League's founding became more formal and culturally neutral, the mandates regime remained grounded in explicitly civilizational hierarchies. Conditions devised in the I930s for the release of polities from a mandate (albeit not strictly applied) were considerably more demanding than those for admission to the League by Ethiopia, never subject to a mandate.

The development of criteria for admission to the League for those polities that were neither original members nor invited to accede to the Covenant was shaped in part by the dynamics of the institution. As all members would have some (admittedly unequal) say in decision-making, there were incentives for the great powers to avoid a proliferation of smaller members. The notion of collective security favored only admitting polities that could make some, even nominal, military contribution. As Zimmern observes, in decisions about membership, one could see "legalism at grips with considerations both of a realistic and of an ethical order." 28

Although Wilson had sought to include a requirement of popular self-government in 
criteria for admission, it proved difficult to find a test that could accommodate the diverse polities thought to merit membership. ${ }^{29}$ Article I of the Covenant ultimately retained only faint traces of a substantive threshold:

Any fully self-governing State, Dominion or Colony [qui se gouverne librement] . . . may become a Member of the League if its admission is agreed to by two-thirds of the Assembly, provided that it shall give effective guarantees of its sincere intention to observe its international obligations, and shall accept such regulations as may be prescribed by the League in regard to its military, naval and air forces and armaments.

Confronted with the first applications for membership, the League's Fifth Committee (comprising representatives of all League members) seems to have felt a need for some detailed assessment of potential members, but there was little principled examination of the issues involved. ${ }^{30}$ The Fifth Committee simply adopted a questionnaire proposed by Viviani, a French delegate:

(a) Was [the applicant's] application for admission to the League in order?

(b) Was the Government applying for admission recognized de jure or de facto and by which States?

(c) Was the applicant a nation with a stable government and settled frontiers? What were its size and its population?

(d) Was it fully self-governing?

(e) What had been its conduct, including both acts and assurances, with regard to (i) its international obligations; (ii) the prescriptions of the League as to armaments?31

Each application went first before a small subcommittee of delegates who met in private; their deliberations were presented to the Fifth Committee in a report, later published. The Committee's own deliberations were open, with reasonably detailed minutes published. The Committee in turn, drafted a report for the plenary assembly.

The Viviani questionnaire mingled language from the Covenant ("fully selfgoverning," and assurances regarding international obligations and armaments) with prewar recognition practice and basic practical desiderata (for example, stable government and settled frontiers). Although Gong sees in the questionnaire "a codified expression of the standard of 'civilization," " the questionnaire actually makes less explicit reference to structures of political authority, or internal administration, than had featured in nineteenth-century accounts of the "civilized" state. ${ }^{32}$ Such considerations were captured only obliquely, in references to "stable government" and ability to satisfy international obligations. The loss of focus on internal political structures is reflected in the way in which different conceptions of "self-governing" (absence of other polities claiming authority over the applicant; and presence of democratic modes of government) flicker through early admission cases. ${ }^{33}$

On the surface, the absence of explicit reference to internal structures of political authority is surprising. Under the Covenant, states were assuming novel responsibilities, including, under article Io, the preservation of the territorial integrity and political independence of all members against external aggression. One might therefore have 
expected greater attention, for example, to a basic Weberian notion of monopoly of force over a fixed area. The absence of such a conception may have been due to the fact that Viviani was likely focused on ensuring strict scrutiny of any future German application. ${ }^{34}$ He may simply have assumed that the German government would be able to overcome postwar disorder, and thus focused more on what were, for France, the key issues: "guarantees of [an applicant's] sincere intention to observe its international obligations" (in the Covenant's words), and the ability to investigate an applicant's conduct and acts under paragraph (e) of the questionnaire.

Aspects of the Viviani questionnaire fell quickly by the wayside. Latin American delegates contested recognition as a condition of membership, and in practice this criterion was read loosely. Early admissions indicated that, as a matter of practicality, admission would entail eventual recognition of the state (if not government) by most League members. ${ }^{35}$ Recognition, previously a discretionary and bilateral process, was thus partly superseded by majoritarian decision-making about admission into the international community-although the absence of the United States and the USSR from the League precluded this shift from being wholly entrenched. ${ }^{36}$

In legal terms, the Viviani questionnaire was not determinative. League members had the right to vote as they wished on applications for admission (and arguably might vote against admission even if they believed the applicant satisfied criteria in article I(2) of the Covenant). ${ }^{37}$ However, the parameters of the questionnaire, together with the formalized and partly public nature of discussions, seem to have limited the sorts of arguments that delegates felt comfortable raising against admission. At least in Committee sessions, objections were lodged within the questionnaire's categories, and even then with diffidence. Certain contested cases related essentially to doubts about the political intentions of former central powers. Applications from some Caucasus states (Ukraine, Georgia, Azerbaijan, and Armenia) and Baltic states (Latvia, Estonia, and Lithuania) were subject to serious questions concerning stability of government, territory, and borders. Given ongoing conflict in the Soviet Union, there was a reluctance to make any undertakings in their defense. ${ }^{38}$

On the other hand, discussion reflected an impetus for inclusion at the expense of a strict application of the Covenant or questionnaire criteria. ${ }^{39}$ The admission in I92I of the Baltic states was urged not despite, but because these states "were experiencing great political, financial, and commercial difficulties." ${ }^{40}$ Provided there was some government in place, even if "not of the most elaborate description," and defensible borders, even instability of government did not preclude admission — and was sometimes weighed against factors such as "strong national sentiment" and a "definite . . . race, speaking a common . . language." 41 Where the Fifth Committee supported applications, the plenary assembly tended to vote unanimously or near-unanimously in favor, in a spirit of celebration at the League's expansion. The only concession to anxieties about internal administration was a proposal to impose on some new states minority protection obligations, analogous to those imposed by some of the peace treaties. However, there was uneasiness among other delegates about imposing additional conditions, and the idea was ultimately confined to Albania and Baltic/Caucasus states, and framed as a recommendation. ${ }^{42}$ 


\section{Ethiopian Admission and the Outer Bounds of the League Community}

Ethiopia presented a unique challenge to criteria for League admission. Unlike some of the Baltic and Caucasus states, Ethiopia enjoyed recognition by major European powers. It also had relatively defined borders. In 1919, Ethiopia was ruled by Menilek's daughter (Empress Zawditu) and Ras Tafari (as regent and heir), and thus enjoyed "stable" government, in that there was no clear rival to the imperial dynasty, despite tensions within it. ${ }^{43}$ (Ras Tafari, educated in French by the head of a Capucin school in Ethiopia, and the son of a trusted collaborator of Menilek, had reformist ambitions, but had to contend with more "conservative" forces in the form of the clerical hierarchy, empress, and the Minister for War). ${ }^{44}$ Ethiopia was "self-governing" in the sense that it was not subject to any formal external influence; however, the imperial court's ability to govern remained constrained by the power of provincial rases, who pursued their own financial and dynastic interests.

While this weakness of central control was not necessarily qualitatively distinct from that seen in some then-chaotic European polities, Ethiopia did present a particularly stark test of the extent to which internal political structures, and the extent of governmental control over territory, might be relevant to League admission. ${ }^{45}$

European powers had tended to see Ethiopia primarily through the lens of imperial interests, albeit of different kinds. Italy nurtured aspirations for territorial gain, and even settlement. France and Britain were preoccupied with territory only as a means of furthering commercial ventures: for France, trade through the coastal colony of Djibouti; and for Britain, construction of a dam on Lake Tana that would serve cotton plantations in the Sudan. ${ }^{46}$ In addition, the European powers had a concrete interest in Ethiopia's internal administration, particularly the capacity to maintain order in the border areas and rein in cross-border slave-raiding. This concern was most acute for Britain, insofar as British colonies shared much longer borders with Ethiopia than French or Italian possessions did.

Within the Foreign Office, officials understood Ethiopia to be formally independent, but also in need of fundamental reordering with the sponsorship of European powers. A British national, Colonel Sandford, who had served in the British legation in 1913-1914, and returned to Addis Ababa in a commercial capacity, laid out the most detailed vision in an unsolicited proposal to the FO in I92I. Sandford saw the fundamental difficulty as "the lack of a stable Government strong enough to impose its will on the chiefs and peoples of the country." In an odd transposition of English history, he likened the situation to "the struggles between the King and the barons . . . of Plantagenet days": the Negus (king) maintained his authority by giving offices and lands as rewards, and crushing any chief who became too powerful, with the effect that the rases lacked security of tenure, and resorted to unstable combinations among themselves to counter the center. Sandford suggested that Britain offer to back Ras Tafari and his heirs as against the rases, on the condition that he offer the rases equivalent security of tenure. This arrangement, Sandford thought, would secure a more stable political structure, and lay foundations for a treaty by which Britain would guarantee Ethiopian independence. ${ }^{47}$ British officials were not averse to projects of this kind, and even believed that "a large portion of the people . . would welcome the establishment of competent administration under pressure by the interested 
powers." ${ }^{48}$ But Britain was forestalled by the Tripartite Agreement from acting alone, and neither Italy nor France would cooperate on the lines envisaged..$^{49}$ Under the circumstances, the FO saw no alternative to "let[ting] Abyssinia totter along and trust[ing] that the inevitable eventual dissolution does not occur until the general political situation is more favourable for dealing with it." 50

On the other hand, anti-slavery activists were envisaging new techniques of intervention in and through the League. The Anti-Slavery and Aborigines Protection Society (ASAPS) took press accounts by former British officials, detailing slave-raiding and trading, and decay in Menilek's work of modernization, as the basis for a public campaign in favor of some sui generis role for the League in Ethiopia. ${ }^{51}$ Arguing (implausibly) that the Tripartite Agreement was already "in the closest harmony with the main principles of the League of Nations," Harris proposed that it be "transfer[red]" to the League. Ethiopia could apply for membership, but would be held not to have the requisite intentions to observe international obligations (slavery being rife); in the interim, the League would extend protection and assistance through commissioners. ${ }^{52}$ Other liberal internationalists agreed: "Strong and independent and progressive African Government" could only be attained with "disinterested assistance." As the commissioners would act for the League, there would be no fear of annexation..$^{53}$ Frederick Lugard, then a key figure in British colonial administration, was skeptical that League commissioners would be welcomed by Ras Tafari unless they brought weapons to match the rases. Commissioners, however, would only furnish such weapons if there was supervision of their use, which Ras Tafari would not accept. For Lugard, the more plausible alternative would be American or British "advisers . . . qualified by African administrative experience," with League supervision or partition into spheres of influence a second resort.

Ras Tafari had made tentative inquiries of French contacts in I9I9 about League membership, seeing this as a vindication of Ethiopia's status, and protection against imperial domination. ${ }^{54}$ However, it appears to have been pressure from anti-slavery activists for something like a mandate that precipitated action. ${ }^{55}$ Ras Tafari persuaded the empress, Fitawrari Habta Giorgis, and important rases and clergy of the benefits, including in relation to access to arms. ${ }^{56}$

The application, made formally on August I, I923, forced states to articulate positions on Ethiopia's status in a manner compatible with the new parameters established by the Covenant and Viviani questionnaire. France was supportive of admission, and helped make the Ethiopian case, if only because a thriving Ethiopia guaranteed commerce through Djibouti. Italy was not disposed to support admission, believing that doing so would undermine what leverage remained under the Tripartite Agreement. However, Italy would change position in the course of deliberations, to avoid needlessly offending Ras Tafari, and to align with France (French support then being required in connection with the Corfu crisis). ${ }^{57}$ Britain was perhaps the most focused of the three European imperial powers on systemic considerations, and British deliberations showcased efforts to reconcile political conditions in Ethiopia with the demands of membership. Echoing longstanding, and circular, arguments over access to arms, officials expressed doubts about the ability of the imperial government to maintain order: 
[If admitted,] either Abyssinia, as a member, would be left to give effective guarantees as provided in Art I of the Covenant, which would mean that France would flood the country with rifles on the pretext that Abyssinia required them to put down slavery; Or Abyssinia would announce its inability to comply with the requirements of the League without outside assistance, which would mean that we, having taken the initiative, should be called upon to do the dirty + expensive work of policing the country, a proceeding fraught with the certainty of political complications with France and Italy. ${ }^{58}$

One commented that if the League "insists on Abyssinia putting her house in order, before admission, then the date of admission will be somewhat remote + will be preceded by a bloody revolution." 59

Misgivings were strengthened by consuls' descriptions of conditions. Governors were not paid by the central government, and could not support soldiers from the surrounding tenant farmers, so permitted them to engage in looting. Slave-raiding was widespread. The consuls understood these issues not simply as a failure of the central government to assert authority, but as a matter of the composition and structure of the polity:

No piece of country south of Addis Ababa is Abyssinia. It all belongs to different and distinct tribes. If Abyssinia . . . said to the Powers, "You bully me because you are strong," exactly the same words could be said by the subject tribes to Abyssinia. . . . One is sorry for Ras Taffari, who has an impossible task in hand. . . The Ras himself can have no idea how this part of Abyssinia has been devastated. The King's writ does not run here. ${ }^{60}$

Officials knew that slavery, in particular, was a problem in mandates and even other potential League member states, but believed its prevalence in Ethiopia indicated "the absurdity of Abyssinia being considered. . . . a civilized or even semi-civilized country." 61 Rennell Rodd, who had negotiated with Menilek in the late nineteenth century, conceded that Ethiopia's ancient Christianity favored admission on civilizational grounds, but reiterated concerns about the viability of Ethiopian statehood. Civilizational and functional considerations were framed in the new language of the Covenant:

How far is Abyssinia a real entity as a self-governing State? Abyssinia consists of a number of kingdoms or principalities, the ruler of one of which from time to time has established his authority as overlord or king of kings. When he has been a strong man like Menelik he has undoubtedly ruled over the whole country, and treated the other princes or rasses as mere vassals. The [current] central Government . . . hardly exercises the control over certain sections of the country which would entitle it to give "effective guarantees of its sincere intention to observe its international obligations." ${ }^{2}$

The FO issued instructions to Robert Cecil, then the British Empire delegate in Geneva, that the application ought not to be accepted, but that this should be "delicately handled" to avoid suspicion that Britain had designs on Ethiopia. ${ }^{63}$ Although the instructions did 
not reach Cecil in time, and he instead followed his own inclinations, they give a useful illustration of the changed circumstances: the FO had not understood that League procedures precluded "delicately" stifling outcomes Britain did not favor. ${ }^{64}$

In the League, Ethiopia's application was sent first to a subcommittee (comprised of representatives of the British Empire, France, Italy, Latvia, Persia, Romania, and Finland). The French representative was quick to head off anticipated objections by proposing a form of declaration concerning Ethiopia's obligations under the Arms Traffic Convention of I9I9. Italy was by this time deciding that it ought not to bear the opprobrium of opposing admission if it seemed impossible to block. ${ }^{65}$ The rubric of the questionnaire channeled discussion in ways that made it difficult to air British objections. As Cecil explained to the FO, the subcommittee's "duty is only to enquire into the facts of the Government of Abyssinia, the extent to which she has carried out her international obligations, etc. ... The whole of the brunt of showing that Abyssinia is not yet fit to become a member of the League has been thrown upon us." 66

Cecil succeeded in introducing some of the British concerns into debate:

The Sub-Committee is of opinion that Abyssinia is fully self-governing, but has not been able to determine with any certainty the extent of the power of the central authority over provinces remote from the capital ... [and] it cannot... state that her engagements have always been strictly fulfilled in the past. ${ }^{67}$

Deliberations in the Sixth Committee illustrated the tensions between competing approaches to statehood and belonging. The Australian delegate spoke an older language of "degrees" of civilization, and defended its ongoing force by reference to the way it grounded the definition of "A," "B," and "C" mandates. ${ }^{68}$ As Parfitt observes, Ethiopia through Ras Tafari engaged in distinctive ways with the civilizational discourse, offering ancient biblical antecedents of the ruling house, and Christian observance, as evidence of a civilization that was distinct yet commensurable with thresholds assumed by international law. ${ }^{69}$ Others resisted as "unwise and dangerous" a "classification which might re-open the way to prejudices of race, caste, colour and nationality," 70 and asserted as the appropriate rubric the more formal criteria developed in the Covenant and League. ${ }^{71}$

Yet the questionnaire criteria were not felt to be satisfactory either. Motta (Switzerland) pointed out that the question of the central government's power over remote provinces "was a very important one," and favored further inquiries. ${ }^{72}$ The Venezuelan representative, continuing earlier Latin American objections to imposing conditions other than those in article I of the Covenant, called this "a question of internal politics." ${ }^{33}$ But this "internal politics" was critical to coexistence with other surrounding polities. The British Empire representative tried to insinuate a concern about state capacity back into the four corners of the questionnaire by reverting again to the connection between past failures to uphold engagements and the viability of guarantees as to future conduct. ${ }^{74}$

The repression of slavery, a key signifier of civilization in the nineteenth century, reemerged in these debates as a proxy for a new, functional vision of statehood, proper to a League system that arguably demanded greater control over territory than nineteenthcentury arrangements had done. One response from Ethiopia and France was to concede weaknesses in the degree of control that would be functionally optimal, but excuse it on 
the basis that it was not markedly worse than that of "all Colonial Governments." 75 Yet even on this basis, Ethiopia's claim was precarious. Repression of slavery had long been a marker of sound imperial administration so, whether assessed against an implicit model of statehood or empire, Ethiopia appeared frail.

As if conceding that concerns were not captured by the questionnaire, delegates embraced a remedial view of membership: even if an enquiry showed that Ethiopia could not presently undertake the engagements made in its declarations, it ought still to be admitted, as admission "must assist the work of that Government." 76 Following Ethiopian complaints, language about the extent of the central government's power, and fulfilment of obligations in the past, was massaged in the final subcommittee report. But, on French advice, Ras Tafari agreed to declare adherence to an obligation in the Convention of SaintGermain-en-Laye (1919) to, inter alia, "endeavour to secure the complete suppression of slavery in all its forms and of the slave trade by land and sea," to conform to its stipulations on arms importations, and to "furnish the Council with any information which it may require, and to take into consideration any recommendations which the Council may make with regard to the fulfilment of these obligations." 77 The British Empire sensed that further objection would be fruitless. The Sixth Committee and Assembly voted unanimously for admission.

Ethiopia's rapid evolution from a polity assumed by leading powers to be ineligible for membership, to one admitted with universal support, illustrated major shifts in thinking about statehood and belonging under the aegis of the League. The old touchstone of "civilization," with its assemblage of European-style governing and judicial institutions, military prowess, cultural and religious dimensions, was contested, and supplemented, at least on the surface, by new criteria that were considerably less searching on matters of internal political structures and governmental capacity. ${ }^{78}$ (These new criteria would be carried over into the definition of a state in the Pan American Montevideo Convention on the Rights and Duties of States (1933), though the older civilizational language would reemerge in League debates in the 1930s, and remained influential in political rhetoric and legal thought.) ${ }^{79}$

The partial displacement of older civilizational criteria was only possible in conjunction with changes to modes of interstate diplomacy. The shift from a system in which both recognition and subtler determinations of the outer bounds of the "family of nations" were controlled by other (largely European) states or publicists, to one of super-majoritarian determination of applications, and collective, relatively public assessment of candidates, did not eliminate the preponderance of great powers in deliberations. It did, however, mean that if admission was supported by at least one major power, it was difficult for others to build a coalition against admission. Whereas British and Italian governments had been able to agree between themselves in 1919 to exclude Ethiopia as a founding member, these positions were much harder to maintain in the League's public fora, when adverse comments would antagonize the Ethiopian government, other small states, and domestic humanitarian and internationalist constituencies. Moreover, the very existence of the League, and the remedial possibilities it offered, seems to have underwritten an expansive approach to admission.

What might we make of this admission process, both for Ethiopia and for larger histories of statehood? Parfitt argues that League admission reinscribed, rather than 
transcended, older hierarchies: Ethiopia "passed all [the] tests" in the standard questionnaire, and the fact that Ethiopia was nevertheless "forced to accede" to "special obligations" in the form of two treaty articles on slavery and arms imports "constituted Ethiopia's interwar personality as . . both sovereign and less-than-sovereign." ${ }^{80}$ I share the sense that admission to the League involved encoding a "hybrid" personality for Ethiopia. Yet the imposition of specific treaty obligations, while invidious, was only one mark of Ethiopia's subjection (especially as the obligation to suppress slavery, in particular, reiterated one already acceded to by Menilek). ${ }^{81}$ The most telling dimension of admission might be the acknowledged hollowness of the formal criteria as applied. Ethiopia (like the other European polities considered around the same time) might technically have "passed" the tests in the questionnaire, but it was clear that many felt that the questionnaire elided the issue of effective control over territory; and that strict compliance with questionnaire criteria had effectively been waived. This bypassing of formal criteria was linked to a remedial emphasis, and an undertaking to "take into consideration any recommendations which the Council may make with regard to the fulfilment of [Ethiopia's] obligations." While Becker Lorca highlights the way in which formal criteria for statehood privileged territorial control as a means of asserting political independence, and were later harnessed to Latin American arguments for nonintervention, the Ethiopia case suggests another contrasting development. ${ }^{82}$ Territorial control was weak in the outer reaches of the empire. The response was not exclusion, but admission "on credit" (à crédit), with a mechanism for Council oversight: a new model of statehood with a permanent potential for intervention. $^{83}$

\section{Ethiopian State-Making in the Shadow of the League}

The creation of the League had fostered new criteria against which Ethiopia's status would be assessed, and shaped the positions other states could take in that assessment. Yet the League also offered ongoing possibilities for the articulation of Ethiopian statehood. On one hand, it was a site in which Ethiopia could interact with European powers on a footing of greater equality than that which existed in the late nineteenth century, and thus confirm its sovereign status. On the other hand, the League offered procedural mechanisms through which European powers, dominant in the Council, might seek to guide governmental policy. The operation of these dimensions of the League was contingent on the issues at stake, and the interests of the major powers that enjoyed disproportionate influence in the Secretariat and League organs, but the League apparatus itself imposed some constraints.

Ethiopian delegations at the League Assembly were small and made very few contributions in the Assembly or committees, but Ras Tafari did occasionally use mechanisms offered by the League to vindicate Ethiopia's status. ${ }^{84}$ One striking example occurred in 1926. Frustrated by an inability to advance their own interests in bilateral negotiations with Ethiopia, Britain and France entered into an exchange of notes providing that Mussolini would support British requests (a concession for construction of a massive dam on Lake Tana), in return for British support for Italian desiderata (concessions for a railway to loop through Ethiopia connecting Eritrea and Italian Somaliland, and a zone of Italian "exclusive economic influence"). The coordination of these far-reaching requests was deeply threatening to Ethiopian interests, and the form of the exchange of 
notes - together with the fact it was only shown to Ras Tafari well after the fact-was reminiscent of the Tripartite Agreement of 1906.

At this point, the League made a tangible difference to Ras Tafari's position. He wrote to the League, contrasting assumptions of equality and independence bound up with an admission that "two Governments are endeavouring to exert pressure on us . . without leaving any time for reflection or consideration for our people's needs." ${ }^{85}$ British and Italian governments were forced to disclaim any coercive intent. ${ }^{86}$ The League involvement invited critical questions, particularly in the British Parliament. Ras Tafari might have had the matter discussed by the Council, but chose instead to simply place on record his view that the exchange was incompatible with the Covenant, and the subsequent anodyne interpretations offered by the governments, which robbed the exchange of its political utility. League procedures offered a forum in which Ethiopia could contest great power machinations on a footing of formal equality, and with the natural sympathies of smaller states.

The prospect of League-sponsored investigation or intervention on slavery, on the other hand, constituted a recurring threat. Perhaps surprisingly, given the terms on which Ethiopian admission was granted, League Council advice or assistance on slavery did not materialize. Indeed, Ethiopia was largely untouched by the more technocratic work of the League and International Labour Organization in areas such as finance, transport and infrastructure, health and labour. ${ }^{87}$ The mandate apparatus engaged comprehensively, if fitfully, in "establishing ... the underlying sociological structure and the political, social and economic substance of the juridical state," and remained a touchstone for those thinking about what the League might do in Ethiopia. ${ }^{88}$ Yet mandate-style oversight was inapposite for a polity recognized as an independent state and already accorded the status of League member. What was absent was any vision of international assistance relevant to Ethiopian conditions but distinct from the imposition of a mandate, or a logic of indirect rule under international advisers.

Left to his own devices, Ras Tafari was increasingly able to pursue his own modernization initiatives (particularly following his coronation as Haile Sellassie in 1930). These reforms mingled personal vision and foreign precedents with bureaucratic and interpersonal experimentation: a form of statecraft that addressed questions like slavery in a wider matrix of relations between center and provinces, educated bureaucrats, and ancient families. ${ }^{89}$ Ras Tafari sketched a centralized polity in Ethiopia's first written constitution, promulgated in I93I. Inspired by English, American, German, Italian, and particularly Japanese sources, the text included a brief catalogue of liberal rights but was primarily concerned with establishing Haile Sellassie's lineage and dynastic transmission, and with furthering centralization..$^{90}$ Crucially, the constitution contained no express reservation of the powers of provincial governors, holding these positions open for the emperor's appointment. Haile Sellassie continued efforts to place the educated elite in positions of importance (overseeing the railway, presiding over the special court adjudicating cases involving foreign nationals, customs posts, envoys) but seems to have tried to sow change from within, allowing older families to hold ministries but appointing an educated reformer as director or executive at a lower rank. ${ }^{91}$ This could advance reforms but could also lead, in cases of ministerial resistance, to "the dislocation of the whole administrative machinery." 92 
In 1932-1933 Haile Sellassie succeeded in breaking the special prerogatives of two of the more independent provincial chiefs. ${ }^{93} \mathrm{He}$ identified "model provinces" ripe for reform, and gave the governorship to trusted collaborators, like Tekle Hawariat (a Russianeducated protégé of Ras Makonnen, Ras Tafari's father), and Workneh Eshaté (anglicized as Dr. Charles Martin; an Ethiopian taken as a child from the battlefield during Britain's I868 expedition, and educated in India). Haile Selassie also experimented with appointing advisers directly to the provincial government, nominating Colonel Sandford (of long residence in Ethiopia, and working both for his own commercial interests and occasionally for the British government) in Maji. ${ }^{94}$ These figures seem to have sought some guidance from colonial models, but in the context of what they understood as a complex interplay between central and provincial authority, reformist and traditional mores. ${ }^{95}$ The provincial reorganization unfolded under the personal control of Haile Sellassie, reflecting a tension like that with ministerial reform, whereby centralization was achieved by the personalization of rule. This was not uncontested. Tekle Hawariat occasionally resisted Haile Sellassie's personalization of authority, and Ethiopian educated élites sometimes resented the greater influence and pay offered to foreign advisers. ${ }^{96}$ In the 1930s, Haile Sellassie began censoring views expressed by some reformists in the newspaper he himself had established. ${ }^{77}$

Comparison of the initiatives undertaken by Ras Tafari and others with the relatively undeveloped proposals for assistance under League auspices illustrates the limits of international expertise and imagination concerning state-making. These limits of the League's ability to advance reform in Ethiopia were clearest in connection with slavery, precisely the area in which the League had been anticipated to act most boldly. Ethiopia always featured prominently in the fact-finding efforts of the League's "Temporary Commission on Slavery" (1924-1925) and its successor bodies, but the League did not progress to intervention of the kind that many antislavery groups had envisaged in $1919 . .^{98}$

To some extent, the lack of action through League bodies was due to interimperial rivalries, which Ras Tafari played to his advantage. The French government largely shielded Ethiopia from criticism. The Italian expert, too, showed little interest in slavery before the I930s. The British position was more varied, torn between a desire on the part of government officials and "experts" like Lugard to see change, and an inclination to use the threat of criticism as a bargaining chip in the service of other imperial agendas.

Yet the lack of action was also a reflection of the limited expertise that the League, or antislavery bodies, could actually offer. While proposals for action under League auspices showed some grasp of the interconnectedness of slavery and the slave trade with the local economy and center-province relations, there was little sense of how to go about addressing these interconnections. Matters came to a head with a resurgence of attention to slavery, the creation (with U.S. pressure) of a special commission to investigate forced labor in Liberia, and appointment in 193I (with British pressure) of a new League "Committee of Experts on Slavery" (CES). Alarmed by the Liberian precedent, Haile Sellassie asked the Anti-Slavery and Aborigines Protection Society (ASAPS) (one of the leading antislavery organizations) to send a mission to advise him. This could have been a vehicle for the behind-the-scenes assistance the FO had sometimes contemplated (particularly on funds to free slaves, and means of occupying them after release). But the ASAPS sent Lord NoelBuxton, a longstanding antislavery campaigner but without detailed knowledge of 
Ethiopia, and unlikely to have practical insights. On Noel-Buxton's visit in 1932, Haile Sellassie agreed to proposals for slavery judges, police, and enforcement; however, NoelBuxton prioritized European humanitarian audiences, submitting his report to the League without first showing it to Haile Sellassie, and mentioning in the Times the prospect of a League mandate over Ethiopia. Sandford, then an adviser to Haile Sellassie, reported with frustration that this was hindering progress. ${ }^{99}$

In the CES, Lugard used the Noel-Buxton report to press again for a League adviser and perhaps League funding. This time, the Italian expert, too, embraced the opportunity to depict Ethiopia as hopelessly backward. ${ }^{100}$ The usual support from the French expert, who argued for Ethiopia's right to comment on the report and evidence, and reports from the British adviser to the Ministry of the Interior detailing reforms, held back more comprehensive inquiries. ${ }^{101}$ But it is not clear that these inquiries could have produced any more nuanced program of reform than those being developed iteratively in the "model provinces."

The fact that the League's engagement with Ethiopia, even on slavery, turned out to be rather limited, is not to downplay the power inherent in the perpetual possibility of more decisive League action. But the limits of the actual expertise on offer does reflect, again, the ambivalence of contemporary notions of statehood. In moving from imperialism to quasi-universal international organization as the basic structure of the international legal order, there was a critical evasion of the question of how to bring states into being. Neither the parsimonious and somewhat artificial criteria for admission, nor the more fine-grained institutional dealings with polities once admitted, grappled with the relation between juridical status as states and League members, reform on specific questions such as slavery, and the larger structural issues of center-periphery relations with which Ras Tafari was preoccupied.

As geopolitical circumstances shifted in the I930s, Ethiopia's status as a League member came under pressure. As Parfitt argues, the developments of the I930s are not so much a contradiction of Ethiopian admission as an exploitation of the conceptual and procedural vulnerabilities entrenched by the admission process. ${ }^{102}$ However, admission had nevertheless entailed certain protections. Relative to its stated ideals-and the protections to which Ethiopia was formally entitled - the League failed utterly; but, relative to a position in which Ethiopia was not a member at all, the League offered juridical and institutional avenues for the preservation of statehood.

After Italy drew Ethiopia into a border incident near the undemarcated boundary between Ethiopia and Italian Somaliland, the dispute was channelled first into an arbitration that ultimately found neither party responsible. A "Committee of Five" drawn from the Council proposed a "Charter of Assistance" to Ethiopia which combined the recurring recourse to mandate-like structures with outright "colonial appeasement." 103 Even this was rejected by Italy. A Committee of Thirteen (i.e., all Council members, except Italy) then prepared a report on the situation, but Anglo-French imperatives to placate Italy undermined the sanctions regime.

These exchanges offer a retrospective lens on the significance of admission for Ethiopia's status. Just prior to invasion, the Italian Government submitted a long memorandum to the Council, which cast Ethiopia as the negative of a legitimate state: a treaty-breaker, a slave state, indeed, not a state at all, but rather a failed and exploitative 
colonial administration by a small "Abyssinian" polity of much larger, and very distinct, populations. ${ }^{104}$ The memorandum combined a focus on treaty compliance, and Ethiopia's failure to adhere to its "special obligations" (criteria that had been discussed on admission) with general complaints about a lack of internal order (something not central to the admissions criteria, but a preoccupation of the delegations in 1923), and general language about civilization and barbarism in the treatment of prisoners and the ill. The Committee of Five's proposed "Charter of Assistance" had defaulted to an imperialistic model of intervention that implicitly accepted critiques of this nature. Yet once the Charter of Assistance was rejected by Italy, and the Committee of Thirteen had to consider the Italian memorandum, it defended Ethiopia's position by invoking precisely the status granted "on credit" in 1923.

When Italy complained that Ethiopia had not respected the special obligations attached to its admission, the Committee read these special obligations as reserving an exclusive role for the Council to make recommendations. The fact that there had been no proposal for the Council to do so became a means of undermining Italy's unilateral criticisms. ${ }^{105}$ As for border raids, the Committee pointed to the "great difficulty of ensuring the application by the subordinate provincial authorities of the policy of the Central Government." The lack of control over territory figured as a means of defending Ethiopian status, not attacking it. And insofar as Italy tried to use internal disorder as a complaint in its own right, the report pointed out that:

the Governments which, in 1923, supported Ethiopia’s request for admission . . . were aware of the internal situation of the Empire at that time . . . [and] considered that the entry of Ethiopia into the League would not only afford her a further guarantee for the maintenance of her territorial integrity and independence, but would help her to reach a higher level of civilisation. There does not appear to be more disorder and insecurity in Ethiopia to-day than was the case in $1923 .{ }^{106}$

In other words, Ethiopian admission had been granted on a basis that may have diverged from that prevailing in other states, but that admission created rights that could not be contested by invocation of more general criteria of "stateness" or "civilization." The Council was willing to contemplate subjecting Ethiopia to a regime of quasi-colonial rule under nominal League auspices, but not an unmaking of the state altogether on Italian demands.

In procedural terms, the League gave Ethiopia some minimal claim to be heard. The Ethiopian delegation filed responses refuting the accuracy of the Italian memorandum, pointing out that any lack of control on the empire's fringes was not dissimilar to patterns seen in European empires, and seeking an international commission of inquiry to ascertain the true position. The impact of these representations was limited to a large extent by the great powers' influence in shaping League procedure, and the outlook of the Secretariat. The then-Secretary-General, Joseph Avenol, and Secretariat staff helped curb the publicity of discussion and avoid open confrontation with Italy. ${ }^{107}$ This discretion dissuaded recourse to the Assembly and postponed League discussions in order to accommodate ad hoc negotiations. ${ }^{108}$ Secretariat decisions amplified Italian positions and marginalized Ethiopian ones. Excuses were found, for example, not to circulate a letter from Dr. Martin, 
then Ethiopian Minister in London, mentioning the torture of an Italian political prisoner and contending that "the Fascist form of Government is by no means suitable for Colonial administration, and that people living in glass houses are ill-advised to throw stones."109 Council members did not publicize Italian gas attacks in Ethiopia, ${ }^{110}$ and correspondence to the Secretariat registering British liberal opposition to the invasion was carefully managed. ${ }^{111}$ Yet efforts to bar Ethiopian access to the Assembly and Council by ruling their credentials invalid did not succeed. ${ }^{112}$ Haile Sellassie's personal appeal to the League Assembly in 1936 helped build powerful popular support in Britain and the United States for the Ethiopian cause. Thus, regardless of the micromanagement of particular statements by the Secretariat, and the limits on Ethiopian ability to make full use of the League machinery, the narratives for which the League provided a formal stage may have helped preserve the Ethiopian state as an international actor, strengthening claims for independence after WWII. ${ }^{13}$

\section{The Interwar Episode in Twentieth-Century Chronologies of Statehood and State-making}

The Italian invasion was a violent caesura in state-making within Ethiopia itself. It drove Haile Sellassie into exile in Britain, dissolved solidarities between leading reformists, and saw the systematic slaughter of intellectual élites. ${ }^{114}$ Despite the violence and disruption of the Italian occupation, however, there were continuities in both the juridical status of Ethiopia, and concrete practices of state-making. In the abstract retrospection of international law, Ethiopian statehood never actually disappeared. ${ }^{15}$ Britain, France, and other states had recognized Italian sovereignty over Ethiopia by 1938, but this recognition was withdrawn by Britain in November 1940, and the British government declared in 194I that it would welcome the re-emergence of an independent Ethiopia under Haile Sellassie. After the defeat of Italian forces in Ethiopia, authority was exercised by an unstable combination of the emperor, the British military forces, and the (British) Occupied Enemy Territory Administration. ${ }^{116}$ An Anglo-Ethiopian Agreement of 1942 recognized that Ethiopia was "free and independent," albeit subject to British oversight in crucial matters ("for all practical purposes a British protectorate"). ${ }^{117}$ With the prospect of U.S. support, and the appointment of John Spencer, who would become a longstanding American legal adviser, to the foreign ministry, Haile Sellassie was able to secure a less overbearing AngloEthiopian treaty in $1944 .{ }^{118}$ In keeping with the theory that the Ethiopian state had persisted despite the temporary destruction of all independent government, Ethiopia took its seat in the UN by right, as a founding member.

On the ground, state-making activities after WWII followed many of the patterns seen in the interwar years. Several individuals who had served as advisers in the 1930s played a role in the wartime administration and beyond. ${ }^{119}$ Tendencies toward centralization and absolutism, central elements of Haile Sellassie's interwar efforts, were crystallized in the 1955 Constitution. ${ }^{120}$ Indeed, British involvement advanced centralization by marginalising Ethiopian republicans who favoured popular rule and federalism. ${ }^{121}$

One can also see important continuities between the way the League's admissions criteria crystallized and framed questions of legal status, and the way such questions were approached in the UN. Under article 4(I) of the UN Charter, criteria for admission of 
states after the founding of the UN was, as in the League, relatively minimalist: "peaceloving states" ("state" then being roughly as defined in the Montevideo Convention), which accept Charter obligations, and, in the judgment of the UN, are "able and willing" to meet them. ${ }^{122}$ Admission of new members operated much as it had under the League, effectively driving (although not superseding in a juridical sense) bilateral recognition, and admission came to be considered conclusive of the fact of statehood. ${ }^{123}$ The institutional context of decision-making about admission remained important (though the Charter's reference to Security Council recommendation gave the major powers an effective veto over membership which the League Council had not enjoyed). As in the League, practice moved rapidly away from literal application of even the minimalist article 4(I) criteria toward an aspiration to universality. The question of whether an applicant was a "state" remained important, but deliberations tended to turn on doubts about the plausibility of territorial claims, and whether polities were genuinely independent, rather than features of their internal government. Well before the wave of decolonization, a precedent had been set for avoiding any searching inquiry into whether newly independent states satisfied article 4(I). ${ }^{124}$

Despite superficial continuities in the minimalist definition of statehood, however, the Charter order implied major changes to how statehood functioned within a larger international legal order. The greater emphasis on individual rights relative to the 1920 s legitimated a certain international scrutiny of, and concern with, the internal government of states that had been bounded under the League by specific regimes, like that for minorities. The international order increasingly also looked inside empire-states, as "selfdetermination" was given new force and legal articulation. With decolonization came further entrenchment and operationalization of the link seen already in the League era, between an expansive approach to admission criteria, on one hand, and far-reaching possibilities of international oversight, on the other. After WWII, international organizations like the UN became more sophisticated and far-reaching vectors of expertise, supporting or even leading the sorts of "state-making" projects that Haile Sellassie had pursued in the interwar period. In situations of conflict or crisis, dispute settlement, peacekeeping, and "transitional justice" processes addressed acute questions about the locus of political authority. ${ }^{125}$ Often mediated by international institutions-if still dominated by major powers - such processes linked status in international law, and admission to international organizations, with the reformulation of internal constitutional and political arrangements. ${ }^{126}$ If the definition of statehood as such remained thin, functional, and loosely applied, the task of, and expertise in, state-making spread itself through new institutional and disciplinary sites.

These patterns are reflected in the Horn of Africa, as elsewhere. Having earlier espoused an understanding of Ethiopia as an empire, Haile Sellassie argued after WWII for narrow definitions of colonialism and non-self-governing territories as those geographically separate from the metropole. This insulated Ethiopia formally from fissiparous demands for decolonization, but not from the reality of ongoing tensions with Eritrea and peoples in the south. The Derg regime, which overthrew Halle Sellassie and ruled from 1974 to 1987, emphasized the unity of the Ethiopian state, but opened inquiries which recognized the political significance of ethnic difference. The surrounding colonies each had troubled passages into statehood, with "self-determination" a recurrent argument if not solution; 
and Ethiopia's current constitution incorporates self-determination for "nations, nationalities and peoples" through subfederal states. ${ }^{127}$ The Horn of Africa has seen a pattern of international involvement in maintaining statehood through the UN and other international and regional bodies, in everything from the unusual "federation" between Ethiopia and Eritrea brokered by the UN, to various peacekeeping missions, and extensive international involvement in shepherding into existence the Republic of South Sudan. ${ }^{128}$

Although the post-I945 history of the Horn of Africa is highly complex, the Ethiopian trajectory can, I maintain, prompt us to look again at dominant narratives about the changing nature of statehood over the twentieth century. One such narrative suggests that post-WWII decolonization broke fundamentally with pre-WWII emphasis on effectiveness for statehood and recognition. On this account, decolonization gave rise to states " 'posited' by international society," the continued existence of which depended on a "superstructure" of international law and the UN. ${ }^{129}$ These accounts are open to criticism in multiple grounds, but Ethiopia, often erroneously listed among the "quasi-states" or "failing states" emerging from decolonization, presents a particular chronological and analytical challenge. ${ }^{130}$

If Ethiopia does share certain common traits with surrounding decolonized polities, many of these traits turn out to be intimately related to questions about internal structures that were raised, if only tentatively, in the I920s. The ambiguities of self-determination in multi-ethnic polities, and the fragility of political order within arbitrary boundaries, are familiar artefacts of decolonization, but they are also merely continuations of longstanding difficulties in center-periphery relations, and in building a machinery of state capable of functioning in the distinct conditions of Ethiopia, with which Ras Tafari had grappled. If there is a disjuncture between effectiveness of authority and formal status in the twentiethcentury international legal order, its origins long predate 1945, and are particularly apparent in the interwar period.

\section{Refractions of Statehood and Belonging}

As sketched here, the League altered pre-WWI debates over statehood and membership in the international order in complex, and sometimes contradictory, ways. The need to articulate thresholds for admission saw a shift away from nineteenth-century understandings of a loose "standard of civilization." This involved a superficial bracketing of religious, cultural and racial dimensions, but also a turning away from explicit consideration of internal political structures and governmental capacity at exactly the moment when a changing international order seemed to demand greater emphasis on these matters. This shift was prompted in part by the changes wrought by the League to modes of interstate interaction, particularly the move to relatively open forums in which major powers felt constrained in their public pronouncements. In the circumstances, formal thresholds were implicitly waived, and membership for marginalized polities recast as a process of reform, rather than recognition of settled status. This invited the sorts of opportunistic imperial assertion seen in the 1930s, in which older civilizational discourses surged back, intermingled with League-inflected designs. As Parfitt has elaborated, conditional admission and the procedural possibilities of the League were deployed powerfully against Ethiopian independence. However, they also helped preserve the outlines of a statehood which might otherwise have remained entirely subsumed after 1945 . 
And, while ignoring none of the devastating effects of the colonial appeasement contemplated in the League in the I930s, it is striking that the League incubated so little of the actual state-making it promised. What it offered, in increasingly coercive form, was the old expertise of colonial administrators: a sort of indirect rule that was too static for the political transformations that Ras Tafari was trying to accomplish. Seen in this light, Ethiopia is not a "failed state" avant la lettre, but a marker of where a certain effort to think through the nature of the state- under conditions of international organization-failed first, opening questions which remain pressing today.

\section{NOTES}

With thanks to Nehal Bhuta, Guy Fiti Sinclair, and other workshop participants; colleagues in the Lauterpacht Centre for International Law; and Duncan Bell, Maja Spanu, Stephen Wertheim, and Natasha Wheatley, for valuable discussions.

I here use "Ethiopia" as the term preferred by the Ethiopian government in the twentieth century. Unless otherwise specified, translations from French are my own. Spelling of Ethiopian terms generally follows secondary literature.

I. Agreement between the United Kingdom, France, and Italy respecting Abyssinia, signed at London, December 13, 1906 [Cmd 3298], art I(a). See Edward C. Keefer, "Great Britain, France and the Ethiopian Tripartite Treaty of 1906," Albion I3, no. 4 (198I): 364-80.

2. Robert L. Hess, "Italy and Africa: Colonial Ambitions in the First World War," Journal of African History 4, no. I (March 1963): I05-26; Peter J. Yearwood, "Great Britain and the Repartition of Africa, I9I4-19," Journal of Imperial and Commonwealth History 18, no. 3 (1990): 316.

3. Papers Relating to the Foreign Relations of the United States IgIg: The Paris Peace Conference, vol. I (Washington, DC: Government Printing Office, 1942), 298, 314.

4. League of Nations Official Journal Special Supplement $\mathrm{I3}$ (1923): 125 (hereafter LNOJSS).

5. Curzon to Cecil, September I7m 1923, Foreign Office files, National Archives, Kew, 371/8410 [A 5519/ 5097/I] (hereafter FO).

6. Shifts evident, and further entrenched, in disciplinary orientations. In legal terms, for example, Ethiopian statehood dates from the late nineteenth century, if not earlier, whereas some social scientific accounts suggest that state-making began only after WWII, and may be ongoing; see, for example, Christopher S. Clapham, Africa and the International System: The Politics of State Survival (Cambridge: Cambridge University Press, 1996), 7-I4; John Markakis, Ethiopia: The Last Two Frontiers (Boydell \& Brewer, 20II), I4-I7, Io8; Alex de Waal, The Real Politics of the Horn of Africa: Money, War and the Business of Power (Cambridge: Polity Press, 2015), 155-73.

7. See, for example, Jochen von Bernstorff, The Public International Law Theory of Hans Kelsen: Believing in Universal Law (Cambridge: Cambridge University Press, 2010).

8. See, for example, Eric D. Weitz, "From the Vienna to the Paris System: International Politics and the Entangled Histories of Human Rights, Forced Deportations, and Civilizing Missions," American Historical Review II3, no. 5 (December 2008): 1313-43; Tara Zahra, "The 'Minority Problem' and National Classification in the French and Czechoslovak Borderlands," Contemporary European History 17, no. 2 (May 2008): 137-65; Volker Prott, The Politics of Self-Determination: Remaking Territories and National Identities in Europe, I9I7-I923 (Oxford: Oxford University Press, 20I6); Leonard V. Smith, Sovereignty at the Paris Peace Conference of IgIg (Oxford: Oxford University Press, 2018).

9. On the importance of the (great) "power" as distinct from the "state," as an actor in international society, see Edward Keene, "The Naming of Powers," Cooperation and Conflict 48, no. 2 (June 2013): 268-82. Keene and Simpson converge in their emphasis on stratification and hierarchy alongside new legal instantiations of sovereign equality: Edward Keene, "The Standard of 'Civilisation,' the Expansion Thesis and the 19th-Century International Social Space," Millennium 42, no. 3 (June 20I4): 65I-73; Gerry Simpson, Great Powers and Outlaw States: Unequal Sovereigns in the International Legal Order (Cambridge: Cambridge University Press, 2004).

Io. Arnulf Becker Lorca, Mestizo International Law: A Global Intellectual History 1842-I933 (Cambridge: Cambridge University Press, 20I4), 266.

II. Rose Parfitt, "Empire des Nègres Blancs: The Hybridity of International Personality and the Abyssinia Crisis of 1935-36," Leiden Journal of International Law 24, no. 4 (December 201I): 849-72; Robbie Shilliam, "Intervention and Colonial-Modernity: Decolonising the Italy/Ethiopia Conflict through Psalms 68:31," Review of International Studies 39, no. 5 (December 2013): II40. Since the present essay was written, Parfitt has published The Process of International Legal Reproduction: Inequality, Historiography, Resistance (Cambridge: Cambridge University Press, 2019). This work illuminates in rich data the developments traced here, but I can refer to it only sparingly.

I2. See, for example, Georg Schwarzenberger, "The Rule of Law and the Disintegration of the International Society," American Journal of International Law 33, no. I (January 1939): 64-65; Mark Mazower, "An 
International Civilization? Empire, Internationalism and the Crisis of the Mid-Twentieth Century," International Affairs 82, no. 3 (2006): 553 .

13. Gerrit W. Gong, The Standard of Civilization in International Society (Oxford: Oxford University Press, I984), I4-I7.

I4. Ibid., 24, 32-34. On treaty-making as entailing at least some recognition of de jure sovereignty, see Charles Henry Alexandrowicz, The European-African Confrontation: A Study in Treaty Making (Leiden: Sijthoff, 1973).

I5. See, for example, on British relations with rulers in what would later be Ethiopia: Edward Hertslet, Richard William Brant, and Howard Leslie Sherwood, eds., Map of Africa by Treaty, 3rd ed., vol. II (London: HMSO/Harrison \& Sons, 1909), 419ff.

I6. Art 3. On accession, see Edward Hertslet, Map of Africa by Treaty, 2nd and rev ed., vol. I (London: HMSO/Harrison \& Sons, I896), 48. On the disputed question of whether Italy's "representation" at Brussels strengthened Italy's protectorate claim, see Carlo Giglio, "Article I7 of the Treaty of Uccialli," Journal of African History 6, no. 2 (July 1965): 226; Sven Rubenson, "Professor Giglio, Antonelli and Article XVII of the Treaty of Wichale," Journal of African History 7, no. 3 (November 1966): 446.

17. Richard Caulk, Between the Jaws of Hyenas: A Diplomatic History of Ethiopia (1876-I896), ed. Bahru Zewde (Wiesbaden: Harrassowitz Verlag, 2002), I53-267.

I8. Treaty of Addis Ababa (with Italy), October 26, I896, art 3, CTS I83 (1979): 423. Similar recognition was implicit in other treaties with European powers, although post-1896 treaties did not, of themselves, unravel agreements which other European powers had made with Italy since I889 in its purported capacity as protector.

19. Harold G. Marcus, A History of Ethiopia (Berkeley: University of California Press, 1994), I06-07; Bahru Zewde, Pioneers of Change in Ethiopia: The Reformist Intellectuals of the Early Twentieth Century (Oxford: James Currey, 2002), 23-24.

20. Treaty of Friendship and Commerce between France and Ethiopia, January 10, 1908, art 7, British and Foreign State Papers IOI (1912): 997. Equivalent arrangements applied to other foreign nationals by virtue of "most favored nation" clauses.

21. Kevin Grant, A Civilised Savagery: Britain and the New Slaveries in Africa, I884-1926 (New York: Routledge, 2005).

22. Ian S. Spears, "The Ethiopian Crisis and the Emergence of Ethiopia in a Changing State System," in Collision of Empires: Italy's Invasion of Ethiopia and Its International Impact, ed. G Bruce Strang (Farnham: Ashgate, 2013), 37.

23. John Westlake, International Law Part I: Peace (Cambridge: Cambridge University Press, 1904), 40 (similar treatment appears in the 2nd [1910] edition, without reference to the intervening Tripartite Agreement); Lassa Oppenheim, International Law: A Treatise (London: Longmans, Green and Co., 1905), I57 (listing Ethiopia, along with Morocco, as "full-Sovereign States, but for some parts only within the Family of Nations"); Lassa Oppenheim, International Law: A Treatise, ed. Ronald Francis Roxburgh (London: Longmans, Green and Co., I920), 35, I80, I90. The leading French text, which divided states into "sovereign," "protected," and "vassal" states, had no separate listing for Ethiopia in the 1894 edition. Editions after 1896 placed the entry for "Abyssinia" under "protected" states but noted Italy's 1896 recognition: Henry Bonfils, Manuel de droit international public (Paris: A Rousseau, I894), 99; Henry Bonfils and Paul Fauchille, Manuel de droit international public, 5th ed. (Paris: A Rousseau, 1908), IOS (again, without noting the Tripartite Agreement).

24. Agreement between the United Kingdom, France, and Italy respecting Abyssinia, signed at London, December I3, 1906 [Cmd 3298], art I(a).

25. Agreement between the United Kingdom, France, and Italy respecting the Importation of Arms and Ammunition into Abyssinia, signed at London, December I3, I906 [Cmd 3299], art I. This was in some tension with Ethiopia's position following accession to the Brussels General Act (see note I6).

26. See Georg Schwarzenberger, The League of Nations and World Order: A Treatise on the Principle of Universality in the Theory and Practice of the League of Nations (London: Constable \& Co, 1936), 36-37.

27. David Hunter Miller, The Drafting of the Covenant, vol. II (New York: G.P. Putnam's Sons, 1928), 260-6I, 303. On India, Stephen Legg, "An International Anomaly? Sovereignty, the League of Nations, and India’s Princely Geographies,” Journal of Historical Geography 43 (January 2014): 100-03.

28. Alfred Eckhard Zimmern, The League of Nations and the Rule of Law (London: Macmillan, 1935), 165; see also Alison Duxbury, The Participation of States in International Organisations: The Role of Human Rights and Democracy (Cambridge: Cambridge University Press, 201I), 63-68.

29. Malbone W. Graham, The League of Nations and the Recognition of States (Cambridge: Cambridge University Press, 1933), 3.

30. Contrary to claims that the Fifth Committee "thoroughly investigated the problem": Lilian M. Friedlander, "The Admission of States to the League of Nations," British Yearbook of International Law 9 (1928): 89 .

31. The Records of the First Assembly: Meetings of the Committees, vol. II (Geneva: League of Nations, I920), I59.

32. Gong, Standard of Civilization, 126.

33. Compare, for example, Records of the First Assembly: Meetings of the Committees, vol. II, 220 (Costa Rica); 
The Records of the Second Assembly: Meetings of the Committees, vol. II (Geneva: League of Nations, I92I), 580 (Estonia).

34. Graham, League of Nations, $63 \mathrm{n} 49$ (citing interviews with Secretariat staff).

35. Ibid., 39-4I.

36. Martin Clark, "A Conceptual History of Recognition in International Law," British Yearbook of

International Law 87 (2016): 747-7I.

37. Jean Ray, Commentaire du Pacte de la Société des Nations (Paris: Sirey, 1930), 97.

38. A decision on the Baltic states was postponed to I92I, when they were finally admitted; the Caucasus states were not ultimately admitted; see Friedlander, "Admission of States," 95-96.

39. When the Serb-Croat-Slovene delegate relinquished opposition to Bulgaria's admission, for example, he observed that he was "following most of his colleagues" in "abandon[ing] the strict application of the Covenant." Records of the First Assembly: Meetings of the Committees, vol. II, I94.

40. Records of the Second Assembly: Meetings of the Committees, vol. II, 532 (Nansen).

4I. See, for example, Report of Sub-Committee Vb on the Admission of Albania, Bulgaria, Austria, and Liechtenstein, November 27, 1920, in Records of the First Assembly: Meetings of the Committees, vol. II, 212, 2I4 (dealing with Albania).

42. See Duxbury, Participation of States, 78.

43. This conjunction resulted from a coup displacing Menilek's immediate successor, Lij Iyasu, who appeared to the court too erratic and too drawn to Islam. Marcus, Haile Sellassie I, 3-4; Bahru Zewde, $A$ History of Modern Ethiopia I855-I99I, 2nd ed. (Oxford: James Currey, 200I), I28-3I.

44. Bahru, History, 130-3I.

45. Bahru N. Grovogui, "Sovereignty in Africa: Quasi-Statehood and Other Myths in International Theory," in Africa's Challenge to International Relations Theory, ed. Kevin C Dunn and Timothy M Shaw (Basingstoke: Palgrave, 200I), 29-45.

46. For this regional, hydraulic vision, see, for example, Terje Tvedt, "Hydrology and Empire: The Nile, Water Imperialism and the Partition of Africa," Journal of Imperial and Commonwealth History 39, no. 2 (201I): I73-94.

47. Sandford to Dodds, July 22, I92I, FO 37I/5509 [A 5725/5725/I].

48. Dodds, September 26, I92I, FO 37I/5509 [A 5725/5725/I].

49. Minutes Seymour, October 16, I92I, Sperling and Tyrrell, both October 20, I92I; all FO 37I/5509 [A $5725 / 5725 / \mathrm{I}]$.

50. Minutes Curzon, October 24, I92I; Sperling, October 20, 1921; both FO 37I/5509 [A 5725/5725/I].

51. On this activism, see Suzanne Miers, Slavery in the Twentieth Century. The Evolution of a Global Problem (Walnut Creek, CA: AltaMira Press, 2003), 63-65, 75; Parfitt, Process of International Legal Reproduction, 2019. 52. [John H Harris], "Slavery in Abyssinia. How the League Could Help. A Modern Gordon Needed," Westminster Gazette, April 28, 1922.

53. Gilbert Murray to Editor, Westminster Gazette, May 2, 1922.

54. Pierre-Alype, Sous la couronne de Salomon: L'Empire des Négus. De la Reine de Saba à la Société des Nations [1925], new ed. (Paris: Plon, 1935), 265.

55. Miers, Slavery in the Twentieth Century, 72-74; Amalia Ribi Forclaz, Humanitarian Imperialism: The Politics of Anti-Slavery Activism, I880-1940 (Oxford: Oxford University Press, 2015), 64-66. On Ethiopian decision-making Parfitt, Process of International Legal Reproduction, 294-30I.

56. Lukian Prijac, Lagarde l'Éthiopien: Le fondateur de Djibouti, I860-I936 (Paris: L'Harmattan, 20I2), 27I-28I; on the deft way in which Ras Tafari rendered into Amharic the idea of the League, see Parfitt, Process of International Legal Reproduction, 297-8. France had advised Ras Tafari that, on joining the League, Ethiopia could accede to the Treaty of Saint-Germain, and negotiate for arms supplies under it, rather than being consigned to the "prohibited zone," in which importation was heavily controlled.

57. For the main actors' positions, see Antoinette Iadarola, "Ethiopia's Admission into the League of Nations: An Assessment of Motives," International Journal of African Historical Studies 8, no. 4 (1975): 60I-22.

58. Minute Sperling, July 20, I923, FO 371/8405 [A 4543/I42/I].

59. Minute Dodd, August II, I923, FO 37I/8405 [A 4789/I42/I].

6o. Hodson to Russell, June 6, I923, encl. with Russell to Curzon, August 14, I923, FO 371/8409 [A 5378/ $278 \mathrm{I} / \mathrm{I}]$.

6I. Minute Warner, September 13, 1923. Officials added observations on: Tyrrell, September I4, I923; both FO 37I/8409 [A 5378/278I/I].

62. Note by Sir R. Rodd on the Abyssinian Request for Admission to the League of Nations, August 26, I923, FO 37I/8409 [A 5209/5097/I] (emphasis added).

63. Memorandum for Lord R. Cecil, September 3, I923, FO 371/8409 [A 5205/5097/I].

64. Cecil was anxious not to be too severe on Ethiopia lest the same threshold hamstring Britain's thenplanned attempt to have Iraq join the League; and thought it unwise to ask for effective guarantees on slavery, which he believed could only lead to exclusion: Cecil to FO, September 7, I923, FO 37I/8409 [A 5356/5097/I].

65. FO to Mr. London (Geneva) for Cecil, September 5, I923, FO 371/8409 [A 535I/5097/I].

66. Tufton to Sperling, September I5, 1923, FO 371/8410 [A 5570/5097/I] (emphasis added). 
67. Abyssinia's Application for Admission to the League. Report of the Second Sub-Committee, September I4, I923, LNOJSS I9 (1923): 32 (emphasis added).

68. See, for example, LNOJSS i9 (1923): I2-13, I5, 2 I.

69. Parfitt, Process of International Legal Reproduction, 302-05. The Abyssinian delegation's interventions while at the League may not be wholly reflective of Abyssinian choices. Léonce Lagarde, founder of the Djibouti colony, helped to shepherd the application through the League, and Ras Tafari's French legal adviser, Bellefonds, was reported by British anti-slavery activists to dominate the delegation's discussions with others: FO 37I/8406. That said, Ras Tafari was insistent on receiving reports from the delegation, and retaining ultimate decisionmaking authority: Prijac, Lagarde l'Éthiopien, 274-79.

70. LNOJSS i9 (1923): 20 (Jouvenel (France)).

7I. Ibid., I5 (Louwers [Belgium]). See Becker Lorca, Mestizo International Law, 278-79.

72. LNOJSS I9 (1923): I4.

73. Ibid.

74. Ibid., is (Wood, British Empire).

75. Ibid., 20 (Jouvenel, France) (emphasis added).

76. Ibid., I6 (Motta, Switzerland); also Portuguese and Belgian delegates at I3, I5.

77. The Convention revised the general obligations in the Berlin and Brussels General Acts; hence the need for it to restate the general obligation to suppress slavery and the slave trade; Admission of Ethiopia, Proposal by the Special Subcommittee, A.VI 5 1923; Report of the Second Sub-Committee of the Sixth Committee, revised text, LNOJSS i9 (1923): 34 .

78. They look all the more minimalist when contrasted with those proposed later for the exit of polities from mandatory rule, including that a mandate

(a) ... have a settled Government and an administration capable of maintaining the regular operation of essential Government services;

(b) ... be capable of maintaining its territorial integrity and political independence,

(c) ... be able to maintain the public peace throughout the whole territory

(d) ... have at its disposal adequate financial resources to provide regularly for normal Government requirements;

(e) . . possess laws and a judicial organisation which will afford equal and regular justice to all; League of Nations Office Journal I2 (1931): 2056, 2057 (hereafter LNOJ).

However, these criteria were not strictly applied in the only case of exit from a mandate (Iraq): Susan Pedersen, The Guardians: The League of Nations and the Crisis of Empire (Oxford: Oxford University Press, 2015), 268-86.

79. Listing as qualifications for statehood: “(a) a permanent population; (b) a defined territory; (c) government; and (d) capacity to enter into relations with the other states." On the genesis of the Montevideo criteria, see Becker Lorca, Mestizo International Law, 334-4I; Thomas D. Grant, "Defining Statehood: The Montevideo Convention and Its Discontents," Columbia Journal of Transnational Law 37, no. 2 (1999): 403-458; see note I2.

8o. Parfitt, "Empire des Nègres blancs," 859; see also now Process of International Legal Reproduction, 290-91. Adom Getachew, Worldmaking after Empire (Princeton: Princeton University Press, 2019), 40.

8I. Georg Schwarzenberger, "Rule of Law"; Mazower, "International Civilization?"; contra Jean Allain, "Slavery and the League of Nations: Ethiopia as a Civilised Nation," Journal of the History of International Law 8, no. 2 (2006): 222. Menilek had understood the Brussels obligation: James Rennell Rodd, Social and Diplomatic Memories 1894-190I. Egypt and Abyssinia (London: Edward Arnold, 1923), 165-66. Menilek's predecessor,

Emperor Yohannes, had also signed an 1884 treaty with Britain to prohibit, to the best of his ability, buying and selling of slaves within his dominions, and their import or export: $\mathrm{FO} 93 / 2 / 3$.

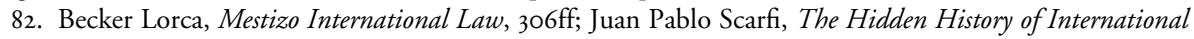
Law in the Americas: Empire and Legal Networks (Oxford: Oxford University Press, 2017), 15I-52.

83. Pierre-Alype, Sous la couronne de Salomon: L'Empire des Négus. De la Reine de Saba à la Société des Nations [1925], ii. Pierre-Alype, a French colonial administrator and businessman, was involved with the admission negotiations.

84. There was a momentary effort to use Chinese campaigns for revision of unequal treaties to revisit the Tripartite Agreement, but this was not pursued: LNOJSS 76 (1929): 47, 55-56.

85. As published in $\mathrm{LNOJ}_{7}$ (1926): 1517.

86. See $\mathrm{LNOJ}_{7}$ (1926): 1524-25.

87. On the increasingly sophisticated "technical assistance" on labor and welfare issues, and, through the I930s, to peripheral polities engaged in modernization projects, see Guy Fiti Sinclair, To Reform the World: International Organizations and the Making of Modern States (Oxford: Oxford University Press, 20I7), 29-IIO.

88. Antony Anghie, Imperialism, Sovereignty, and the Making of International Law (Cambridge: Cambridge University Press, 2005), I48.

89. On Ethiopia's own initiatives on slavery, Christine Whyte, “Everyone Knows That Laws Bring the Greatest Benefits to Mankind': The Global and Local Origins of Anti-Slavery in Abyssinia, 1880-1942," Slavery \& Abolition 35, no. 4 (2014): 657-6I. 
90. Marcus, Haile Sellassie I, in6. On inspiration from the Meiji Constitution, see J. Calvitt III Clarke, Alliance of the Colored Peoples. Ethiopia \& Japan before World War II (Woodbridge: James Currey, 20II), 37-38, 172-73; Tekle Hawariat, as quoted in John Markakis, Ethiopia: Anatomy of a Traditional Polity (Oxford:

Clarendon Press, 1974), 273; Bahru, Pioneers, I82.

91. Bahru, Pioneers, I79-8I, 176-78.

92. Report by Mr. de Halpert on his Period of Service with the Ethiopian Government, May 22, 1934, encl with Barton to Simon, June I8, 1934, FO CP I4809, No 36(i), 77, 8I-82. Halpert, a British adviser to the Ministry of the Interior, had proposed reforms to provincial administration. He faced opposition from the Minister of the Interior, and successive directors, immediately under the minister, were also opposed or, where favorable, blocked by the minister. Halpert resigned in frustration in 1934.

93. Marcus, Haile Sellassie I, In9-24.

94. Sandford's I92I proposal disclaimed mandatory ambitions, but was grounded ultimately in Britain being able to "bring [Ras Tafari] quickly to heel." Sandford to Dodds, July 22, 1921, FO 37I/5509 [A 5725/5725/I]. 95. Peter P. Garretson, A Victorian Gentleman \& Ethiopian Nationalist: The Life \& Times of Hakim Wärkenäh, Dr. Charles Martin (Suffolk: James Currey, 2012), 173-96; Eleanor Casbon, The Incurable Optimists: Chris and Dan Sandford of Ethiopia (Cornwall: United Writers, 1993), 98.

96. Bahru, Pioneers, 169-70, 174-75, 196-97.

97. Ibid., 193.

98. On the work of these bodies, Miers, Slavery in the Twentieth Century, I00-33, 174-79, 197-316.

99. Ibid., I77-79

IOo. Ribi Forclaz, Humanitarian Imperialism, I43ff.

IOI. Miers, Slavery in the Twentieth Century, 20I-O2.

I02. Parfitt, "Empire des Nègres blancs"; Process of International Legal Reproduction, 319, 323.

103. On colonial appeasement, see Pedersen, Guardians, 325-54. For the "Charter of Assistance," see Report by Committee of Five to the Council, September 24, 1935, C.379.M.191.1935.VII in LNOJ I6 (1935): I620. The Charter amounted to a complete takeover of sovereign functions by foreign specialists, ostensibly overseen by a delegate of the League accredited to the Emperor; but the three powers would be heavily involved, and Italy would have special recognition of economic interests as against Britain and France.

I04. LNOJ I6 (1935): I355ff.

I05. Ibid., I6I6.

I06. Ibid., I605, 1618. Part of this statement was quoted by Haile Sellassie in his 1936 speech to the Assembly: see LNOJSS I5I (1936): 23.

107. See, for example, untitled, marked at top in pencil "L'original a été remis à la Section Politique ...., Ministère des Affaires étrangères, papiers d'agents et archives privées, Avenol 29 (hereafter MAE PAAP). I08. See, for example, John H. Spencer, "The Italian-Ethiopian Dispute and the League of Nations," American Journal of International Law 31, no. 4 (October 1937): 640.

I09. Martin to Secretary-General, September 9, 1935; Walters to Martin, September I2, I935; minutes; all League of Nations Secretariat Archives, R3654 [I/19840/15227] (hereafter LNA).

IIo. See, for Britain, Steven Morewood, "The Chiefs of Staff, the 'Men on the Spot' and the Italo-

Abyssinian Emergency, 1935-36," in Decisions and Diplomacy: Essays in Twentieth-Century International History, ed. Dick Richardson and Glyn Stone (London: Routledge, I995), 98.

III. See, for example, [illegible] to Avenol, May 2, 1937, LNA R3649 [I/15227/15227].

II2. See, for example, "Participation de l'Ethiopie à la prochaîne réunion de l'Assemblée de la S.D.N," June I5, I936, MAE PAAP Avenol 29; 'Extrait des Archives Secrètes du Comte CIANO, page 3I. Chapitre III,' MAE PAAP Avenol 29; cf Council minutes, 93rd sess, Ist mtg (private) [September I8, 1936], LNOJ I7 (1936): II38, II39.

II3. Pedersen, Guardians, 297-98; Ribi Forclaz, Humanitarian Imperialism, I90-9I; on African American and black Caribbean mobilization, see Joseph E. Harris, African-American Reactions to War in Ethiopia 1936-194I (Baton Rouge: Louisiana State University Press, 1994), 34-84; Shilliam, "Intervention and Colonial-Modernity," II44-46.

II4. Bahru Zewde, “The Ethiopian Intelligentsia and the Italo-Ethiopian War 1935-194I," International Journal of African Historical Studies 26, no. 2 (1993): $27 \mathrm{I}$.

II5. James Crawford, The Creation of States in International Law, 2nd ed. (Oxford: Clarendon Press, 2007), 519-20, 702-3.

II6. John H. Spencer, Ethiopia at Bay: A Personal Account of the Haile Selassie Years (Algonac: Reference

Publications, Inc, 1984), 95.

II7. Ibid., 99.

II8. Ibid., I40-45.

II9. Sandford, for example, was involved in the British military action, and then served as adviser to Haile Sellassie; see Casbon, Incurable Optimists, 136-38; Asfa-Wossen Asserate, King of Kings: The Triumph and Tragedy of Emperor Haile Selassie I of Ethiopia, trans. Peter Lewis (London: Haus, 2015), 160-6I.

I20. Spencer, Ethiopia at Bay, 130-32. This was drafted with assistance from U.S. experts, and contained a list of rights, but was largely shaped by the emperor's demands; at 256-60. 
I2I. Bahru, History, 176.

I22. Listing as qualifications for statehood: “(a) a permanent population; (b) a defined territory; (c) government; and (d) capacity to enter into relations with the other states."

I23. John Dugard, Recognition and the United Nations (Cambridge: Grotius Publications, 1987), 4Iff; Thomas D. Grant, Admission to the United Nations (Leiden: Nijhoff, 2009), 252-57.

I24. Duxbury, Participation of States, 99; Dugard, Recognition and the United Nations, 67-73; contra Rosalyn Cohen, "The Concept of Statehood in United Nations Practice," University of Pennsylvania Law Review ro9, no. 8 (June I96I): II27-7I. The trend to universality reached its logical conclusion in the I990s with the admission of several "micro-states," in contrast to the exclusion of, for example, Liechtenstein from the League. See Bruno Simma et al., eds., The Charter of the United Nations: A Commentary, 3rd ed., vol. I (Oxford: Oxford University Press, 2012), 347; Grant, Admission, 238-44.

I25. Sinclair, To Reform the World; Anne Orford, International Authority and the Responsibility to Protect (Cambridge: Cambridge University Press, 20II).

126. Bridget Coggins, Power Politics and State Formation in the Twentieth Century: The Dynamics of Recognition (Cambridge: Cambridge University Press, 20I4).

I27. See Alex de Waal and Sarah Nouwen, "The Necessary Indeterminacy of Self-Determination: Politics, Law and Conflict in the Horn of Africa," Forthcoming, n.d., (manuscript on file with author); Mulugeta Gebrehiwot Berhe and Fiseha Haftetsion Gebresilassie, "The Norms and Practices of Nationalism and SelfDetermination in Contemporary Ethiopia," Forthcoming, n.d., (manuscript on file with author); Lahra Smith, Making Citizens in Africa: Ethnicity, Gender, and National Identity in Ethiopia (Cambridge: Cambridge University Press, 20I3), $71-83$.

I28. GA Res 390(V) of I950. On the contested role for the UN in upholding this arrangement, see Spencer, Ethiopia at Bay, 223-48.

129. Robert H Jackson, Quasi-States: Sovereignty, International Relations and the Third World (Cambridge University Press, 199I), 80, 8I; see also, for example, Mikulas Fabry, Recognizing States: International Society and the Establishment of New States Since 1776 (Oxford University Press, 2010), I55-65.

130. See, for example, Krasner's listing of Ethiopia as among states of a "pre-modern world" enjoying "possibly Westphalian, Vattelian sovereignty, but not domestic sovereignty": Stephen D. Krasner, "The Durability of Organized Hypocrisy," in Sovereignty in Fragments: The Past, Present and Future of a Contested Concept, ed. Hent Kalmo and Quentin Skinner (Cambridge: Cambridge University Press, 20Io), Ioo; Spears, "Ethiopian Crisis," 34. 